\title{
OBSTÁCULOS POLÍTICOS À CONCRETIZAÇÃO DO DIREITO À EDUCAÇÃO NO BRASIL
}

\author{
POLITICAL OBSTACLES THAT RESTRAIN \\ THE RIGHT TO EDUCATION IN BRAZIL \\ LES OBSTACLES POLITIQUES À LA CONCRETISATION \\ DU DROIT À L'ÉDUCATION AU BRÉSIL \\ OBSTÁCULOS POLÍTICOS A LA CONCRETIZACIÓN \\ DEL DERECHO A LA EDUCACIÓN EN BRASIL
}

Décio Azevedo Marques de Saes *

\section{RESUMO}

O objetivo do texto é investigar as razões históricas da defasagem entre duas dimensões do processo de concretização do direito à educação no Brasil: a efetivação do direito universal de entrada no sistema escolar e a realização integral do direito de saida do sistema escolar. A conclusão deste estudo é a de que a classe média é o principal agente da instauração e do desenvolvimento do direito à educação no Brasil; e, como as aspiraçōes dessa classe social são socialmente limitadas, são conseqüentemente reduzidas as possibilidades de realização integral do direito universal à educação na sociedade brasileira, enquanto esta estiver conformada ao modelo sócio-econômico capitalista.

Palavras-chave: Educação. Direito. Trajetória. Estratégia. Classe média. Fracasso escolar.

* Doutor em Sociologia pela École des Hautes Études en Sciences Sociales (EHESS, 1974). Pós-doutor na Université de Paris I - Panthéon-Sorbonne (UP I, 1980). Livre-docente na Universidade Estadual de Campinas (Unicamp, 1983). Professor Titular da Faculdade de Educação e Letras da Universidade Metodista de São Paulo (mdsaes@uol.com.br). 
Todos os que acompanham o desempenho do atual governo têm notado, com apreensão, que a sua incapacidade política em encaminhar reformas progressistas nos terrenos da política econômica e da política social - incapacidade essa que se articula sintomaticamente com a sua inclinação a encampar propostas conservadoras de reforma do Estado - também tem se evidenciado no terreno especificamente educacional. Os governos nacionais da década anterior tinham se colocado a missão de levar adiante a concretização do direito à educação, constitucionalmente sancionado; entendiam, porém, que essa missão equivalia essencialmente à ampliação máxima da oferta do número de vagas no ensino fundamental, com o auxílio dos governos estaduais e municipais, de instituiçôes internacionais como o Banco Mundial e de organizações não-governamentais (nacionais ou estrangeiras). Tais governos trataram, portanto, na prática, o direito à educação como sinônimo da universalização do acesso ao ensino fundamental; ou seja, como direito de entrada no sistema escolar. Essa postura levava a negligenciar o tratamento estatal de problemas da vida escolar que bloqueiam, desde o surgimento no Brasil de um sistema de educação pública, a concretização do direito à educação como direito de saída do sistema escolar: o fracasso escolar, o retardo escolar, a evasão escolar, o iletrismo etc.

Essa contradição entre o avanço do direito de entrada no sistema escolar e a estagnação do direito de saída do sistema escolar é evidenciada por dados recolhidos pelo IBGE (PNAD) no período recente. No fim da década de 1990, mais de $90 \%$ das crianças de 7 a 14 anos estavam integradas ao sistema escolar. No entanto, $57 \%$ dos brasileiros com mais de 15 anos tinham, em 2001, menos de oito anos de estudo. Não se pode dizer que o atual governo nacional tenha dado mostras, até aqui, de poder realizar aquilo que ainda falta para a concretização do direito à educação no Brasil: a viabilização do direito de saída do sistema escolar. Mais especificamente: não se pode dizer que o Ministério da Educação tenha posto em prática, até aqui, uma estratégia de combate frontal ao fracasso escolar, ao retardo escolar, à evasão escolar e ao iletrismo.

De todo modo, o propósito deste artigo não é expressar uma certa decepção com relação ao atual governo federal. É verdade que este tem se encaminhado mais, em vários terrenos da política estatal (sobretudo as políticas sociais), para um reformismo conservador que para um reformismo progressista. Todavia, como pesquisadores, temos de procurar as razóes estruturais e históricas do permanente bloqueio ao avanço do processo de concretização do direito à educação. Esse bloqueio não começou agora; ele existe desde que se estendeu a educação escolar elementar às classes dominadas. Mas tal bloqueio se torna politicamente dramático agora, pois já não pode mais ser atribuído à má vontade de governos socialmente retrógrados como os que se sucederam ao longo de toda a Primeira República brasileira. Quando governos que se reivindicam de programas social-democratas se rendem a tal bloqueio, a explicação para essa acomodação deve ser buscada não na psicologia ou no grau de competência administrativa dos governantes, $\mathrm{e}$ sim em fatores estruturais e históricos. 


\section{UM QUADRO SOCIOLÓGICO DOS OBSTÁCULOS POLÍTICOS À CONCRETIZAÇÃO DO DIREITO À EDUCAÇÃO}

Examinemos tais fatores. Quando lemos os jornais, temos a impressão de que nenhum obstáculo estrutural e histórico à concretização do direito à educação existe. As notícias de jornal nos levam constantemente a pensar que os déficits registrados nesse terreno só podem se dever à má vontade dos governos ou, mais ainda, à sua ineficácia. $\mathrm{E}$ isso porque tais notícias se fazem freqüentemente acompanhar da reprodução do discurso oficial e do estado da opinião pública no que diz respeito à educação; e tanto o discurso oficial quanto a opinião pública afirmam reconhecerem a importância da educação para o desenvolvimento de cada indivíduo e da sociedade como um todo.

Enquanto nos atemos ao universo das declaraçôes oficiais e formais, sejam as do governo, sejam as dos diversos atores sociais, guardamos a impressão de que existe total unanimidade, na sociedade atual, quanto à necessidade de instrução elementar para todos. Colocados diante dessa aparente unanimidade, devemos procurar responder à seguinte questão: se todos são favoráveis à universalização da instrução elementar, por que tem sido tão difícil realizar na prática o direito universal à educação, mesmo quando esse direito está consagrado pela Constituição e é, portanto, reconhecido pelo Estado?

O primeiro passo na abordagem dessa questão consiste em relembrar - nunca é demais - que o direito de todos os "cidadãos" (estando obviamente excluídos dessa condição jurídico-política os escravos) à instrução elementar foi declarado pela Constituição imperial de 1824; e que nem por isso ele foi concretizado durante o Império. Diversos documentos constitucionais criados entre 1934 e 1988 reafirmaram tal direito; e, no entanto, só agora (em pleno início do século XXI) o direito universal à entrada no sistema escolar parece estar em vias de se concretizar no Brasil.

Já o direito de saída do sistema escolar não se concretizou até hoje, e paradoxalmente sua concretização vai se tornando cada vez mais difícil no Brasil, já que a expansão da oferta de ensino fundamental, motivada pelo propósito de concretizar o direito universal de entrada no sistema escolar, vai tornando cada vez mais estreito o gargalo instaurado na entrada do ensino médio. Ou seja: a política de concretização do direito de saída do sistema escolar, quando não conjugada a outras medidas (de política econômica, social e inclusive educacional), vai dificultando ainda mais, em termos relativos, a concretização do direito de saída do sistema escolar.

Ao detectarmos esse paradoxo, vemo-nos colocados diante do fenômeno da coexistência formalmente contraditória entre o acesso tendencialmente universal à educação de base e a escolarização desigual das crianças de diferentes níveis sociais e de renda; ${ }^{1}$ desigualdade essa que se traduz através do fracasso escolar, do retardo escolar, da evasão escolar e, de um modo geral, da curta duração da trajetória escolar das crianças de origem popular. É preciso, portanto, buscar uma explicação sociológica e histórica para a dificuldade de concretização tanto do direito de entrada no sistema escolar quanto do direito de saída do sistema escolar, numa sociedade como a brasileira.

O ponto de partida para essa explicação consiste em relembrar que o direito universal de acesso à educação de base, tal qual ele é declarado por grande parte das Constituições 
atuais, não é, de um ponto de vista técnico-jurídico, um direito subjetivo individual, que possa ser usado ou deixar de ser usado conforme o arbítrio de cada um. Por baixo da aparência formal do direito individual, o que existe no terreno educacional é uma obrigação. Mais precisamente: os textos constitucionais das sociedades burguesas atuais tendem, todos, a estabelecer uma dupla obrigação em matéria educacional. De um lado, instaura-se uma obrigação civil para os pais: é a obrigação de inscrever os filhos na escola e de garantir a freqüência dos mesmos na escola. De outro lado, cria-se uma obrigação política para o próprio aparelho de Estado: é a obrigação de criar as condições materiais mínimas para que os pais possam cumprir a sua própria obrigação de inscreverem os seus filhos na escola e de garantirem a sua freqüência.

A declaração da obrigatoriedade da escolarização de base se desdobra, portanto, num sistema de obrigaçôes cruzadas, que pode dar a impressão falsa de que o Estado está criando um direito subjetivo individual à educação; isto é, instaurando uma prerrogativa que cada pai pode usar ou não, em caráter facultativo, conforme o seu arbítrio. No atual regime constitucional brasileiro, instaurado pelo texto legal de 1988, essa prerrogativa só é real, e não ilusória, no que diz respeito à educação infantil (creche e pré-escola). Pela Constituição de 1988, os pais gozam de fato de um verdadeiro direito subjetivo individual à educação infantil, o que significa que eles têm, nesse nível educacional específico, uma dupla faculdade: a) a faculdade de decidir se os seus filhos freqüentarão creches e pré-escolas; b) a faculdade de exigir que o Estado lhes forneça educação infantil, caso faltem aos pais meios financeiros para tanto. No nível do ensino fundamental, o regime constitucional de 1988 estabeleceu a dupla obrigação mencionada acima: uma obrigação civil para os pais e uma obrigação política para o Estado.

Neste ponto da análise, uma questão se torna incontornável: por que o Estado tem de tornar a inscrição e a freqüência à escola fundamental uma obrigação, se a escolarização universal parece ser do interesse de todos? A resposta está em que a escolarização parece, mas não é do interesse de todos. As declaraçóes unanimemente favoráveis à escolarização universal representam apenas a camada mais superficial da ideologia escolar da maioria das classes sociais; e não a camada mais profunda dessa ideologia, que equivale à ideologia escolar prática. ${ }^{2}$ As classes sociais mais importantes da sociedade capitalista brasileira podem, no plano do discurso, valorizar a educação em geral (isto é, a educação concebida abstratamente como "algo que sempre faz bem ao homem"); e os seus membros podem, no plano da prática individual, tomar providências para que os seus filhos recebam instrução. Porém, nem esse discurso nem essa prática individual implicam defender a instauração constitucional do direito à educação e a concretização da obrigatoriedade da educação de base por meio da ação estatal.

Os agentes da classe capitalista - isto é, os empresários - têm necessidade de que a sua mão-de-obra saiba pelo menos ler, escrever e contar. Em tese, portanto, eles poderiam ser favoráveis a que o Estado garantisse um mínimo de instrução para todos. Na prática, porém, se os empresários de um lado esperam que a sua mão-de-obra não tenha "instrução de menos", eles temem de outro lado que a sua mão-de-obra tenha "instrução demais". 3 A "instrução demais" poderia ser, em primeiro lugar, inconveniente de um ponto de vista ideológico e político, caso ela propiciasse a "conscientização" da mão-deobra e levasse à contestação da legitimidade do próprio sistema empresarial privado. 
Ela poderia, em segundo lugar, criar problemas imediatos na própria organização do processo de trabalho dentro da empresa; uma vez dotado de uma "super-instrução", o trabalhador poderia querer interferir em áreas em princípio sob controle da direção da empresa, como a definição de metas, a proposição de métodos ou o controle de qualidade. Pode-se, portanto, concluir que, no terreno da educação da mão-de-obra, dois fantasmas rondam o empresariado: o fantasma da politização e o fantasma da sobre-qualificação.

Pelas razões acima expostas, é natural que a classe capitalista se mostre reticente, não quanto a um mínimo de educação para a sua mão-de-obra; e sim, quanto à consagração legal do princípio obrigatório da instrução elementar para todos. A formação de um sistema escolar público é sempre politicamente perigosa para a classe capitalista, já que, uma vez constituído tal sistema, ele não pode fugir à influência da burocracia estatal nem à pressão das diferentes classes sociais (classe média, classes trabalhadoras manuais). Intervindo o Estado na educação, o empresariado não teria mais certeza de poder impor as suas concepções e os seus objetivos ao processo educacional. É por isso que a classe capitalista sempre tendeu a equacionar a questão da educação de massa em termos nãoestatais e filantrópicos. Na Primeira República (1889-1930), um número significativo de industriais, não só em São Paulo como também noutros Estados (inclusive os do Nordeste), fornecia educação primária nas vilas operárias instaladas ao lado das suas fábricas. ${ }^{4}$ Mais recentemente - e sobretudo a partir do Regime Militar -, surgiram programas educacionais de caráter filantrópico, implementados sob controle das empresas e beneficiados pelo apoio externo do Estado. Concluindo: mesmo que a classe capitalista não se colocasse ostensivamente contra a obrigatoriedade da instrução elementar, ela nunca poderia ter atuado como um fator poderoso de pressão em prol da obrigatoriedade do ensino elementar.

As classes trabalhadoras manuais, em tese, teriam boas razōes para lutar pela concretização do direito à educação. A instrução elementar, considerada num plano estritamente teórico, parece trazer às crianças de origem popular pelo menos duas vantagens. Em primeiro lugar, ela daria a tais crianças condições mínimas - ler, escrever, contar para que se integrassem ao mercado de trabalho; e, portanto, para que, no mínimo, reproduzissem a condição socioeconômica já gozada pelos seus pais. Em segundo lugar, ela abriria caminho para a ascensão dessas crianças na escala social, dando a partida para uma longa carreira de estudos. Analisada a questão exclusivamente nesses termos, parece razoável que a instrução elementar seja valorizada pelas classes trabalhadoras manuais, de modo alternado ou simultâneo, como instrumento de qualificação da mão-de-obra e de ascensão individual na hierarquia social.

$\mathrm{Na}$ prática, porém, os trabalhadores manuais freqüentemente não têm condições de projetar um futuro para os seus filhos. Submetidos a pressões imediatas de caráter material e financeiro, os trabalhadores manuais acabam tendo de encarar as suas crianças como mão-de-obra presente, necessária à reprodução material de toda a unidade familiar; e não como mão-de-obra futura, a ser progressivamente formada através de um processo educacional de longa duração. Recorrendo à expressão apresentada por Luiz Antonio Cunha na obra já citada: os trabalhadores manuais têm de fazer incessantemente o cálculo dos "custos indiretos da escolarização" dos seus filhos. Esse cálculo corresponde 
à estimativa de tudo aquilo que a família trabalhadora perderia em termos de rendimento monetário, caso a criança se inscrevesse numa escola em vez de se integrar ao mercado de trabalho. Priorizando a reprodução material da unidade familiar, os pais trabalhadores não têm como formular estratégias no plano educacional ou projetar investimentos educacionais em função da previsão de trajetórias escolares absolutamente regulares para os seus filhos. ${ }^{5}$ Como nos mostra Bourdieu, o comportamento educacional das classes trabalhadoras manuais é tendencialmente aleatório. Isso significa, na prática, que os trabalhadores manuais podem ser a favor da educação escolar dos seus filhos, desde que a instrução não se coloque como um princípio absoluto e incondicional, situado acima das necessidades materiais da família.

As classes trabalhadoras manuais não podem, portanto, se alçar ao primeiro plano da luta pela instauração do ensino elementar obrigatório, pois elas pressentem que podem vir a ser as primeiras vítimas sociais dessa obrigatoriedade. Um indício dessa atitude popular é o fatalismo com que muitos trabalhadores encaram a evasão escolar das suas crianças. É como se esses pais pensassem: "Se as nossas crianças, cedo ou tarde, vão ser expelidas do sistema educacional para logo a seguir se integrarem ao mercado de trabalho manual, é melhor que isso ocorra cedo, para o bem presente de toda a família”.

Essas observações sociológicas sobre o comportamento educacional médio das classes trabalhadoras manuais não desmentem, porém, que a presença social das classes populares urbanas tenha influenciado indiretamente, nas sociedades burguesas do século XIX, a posição do Estado capitalista com relação à educação. "O fantasma da revolução proletária” (conforme a expressão empregada por Marx em O 18 Brumário) agiu sobre o espírito da burocracia estatal, mais fortemente na França (palco de revoluções populares em 1830, 1833, 1848 e 1871) que na Inglaterra (onde o movimento cartista chegou a se desenvolver como movimento de massas na década de 1830 , a despeito de não ter se alçado ao terreno da insurreição) ou na Alemanha (onde o partido social-democrata acabou se convertendo, por desfrutar de prestígio junto às classes trabalhadoras, em fator de pressão dentro do governo de Bismarck). De qualquer modo, a presença potencialmente ameaçadora do proletariado urbano pressionou a burocracia estatal de diversos países europeus na direção de uma política educacional "universalista" pelo menos num sentido: o de "educação para todos", embora não "a mesma educação para todos". Mas a motivação burocrática para a implementação de alguma política educacional de âmbito nacional era política, e não econômica: a educação nacional se configurava, para o corpo burocrático estatal, como um importante instrumento de integração ideológica das classes sociais "perigosas" à ordem social vigente.

\section{A CLASSE MÉDIA E A LUTA PELO DIREITO À EDUCAÇÃO}

Se a classe capitalista e a classe dos trabalhadores manuais não podem se colocar no primeiro plano da luta pelo ensino elementar gratuito e obrigatório, que classe social pode assumir a vanguarda na luta pela universalização do acesso à educação de base? Esse papel tem sido regularmente preenchido pela classe média, a que de resto pertencem 
professores, diretores de escola e administradores escolares. A defesa da escola pública e do ensino público gratuito e obrigatório por parte dos representantes ideológicos da classe média pode parecer paradoxal, já que grande parte dos membros dessa classe social não dá mostras de depender estritamente do ensino gratuito para promover a educação dos seus filhos. A preocupação constante da classe média com a qualidade do ensino leva boa parte dos seus membros a matricular os seus filhos em escolas particulares, nos períodos em que a escola pública sofre uma deterioração aguda e a qualidade do ensino parece se refugiar (ou então se refugia de fato) no setor privado. É importante, do ponto de vista sociológico, indicar que, em qualquer situação (carência ou não de recursos financeiros nas famílias da classe média, qualidade do ensino periclitante ou não nas escolas públicas), a classe média sente, no plano ideológico, a necessidade de que exista a escola pública. E isto porque só a escola pública pode assumir, sendo gratuita, a aparência de uma Escola Única, onde em princípio coexistem todas as classes sociais: crianças ricas, crianças de classe média, crianças de origem popular. A escola pública, ao assumir a aparência de uma Escola Única, permite que a classe média suponha a existência de uma competição de saber entre indivíduos pertencentes às diferentes classes sociais. Na realidade, essa competição não existe; ela é apenas simulada. Os agentes do sistema escolar pertencem à classe média e organizam a competição de saber em função de expectativas, princípios e exigências típicos da classe média. A competição de saber se faz, portanto, com "cartas marcadas"; e o resultado final só pode ser o sucesso escolar dos filhos da classe média e o fracasso escolar dos filhos das classes trabalhadoras manuais.

Agora, convém esclarecer que esse simulacro de competição de saber não é uma mera fantasia destituída de qualquer funcionalidade na relação entre as classes sociais; ele se configura antes como um processo ideológico socialmente útil para a classe média. A encenação de uma competição de saber acaba criando, em toda a sociedade, a impressão de que os indivíduos que vão para o topo do sistema econômico (isto é, para o desempenho das funções de concepção, direção e responsabilidade) conquistam essa vitória pessoal apenas pelos seus méritos individuais. Essa simulação é, na verdade, fundamental para encobrir os efeitos produzidos, no plano das trajetórias individuais, pela convergência entre o modelo vigente de sistema escolar e o universo ideológico da classe média.

A difusão dessa impressão acaba exercendo influência sobre o modo pelo qual se desenvolve concretamente a sociedade capitalista, a partir de seus fundamentos imutáveis (expropriação do produtor direto, separação entre os trabalhos de concepção e de execução, subsunção real do trabalho ao capital). Mais especificamente: a impressão, induzida pela aparência da Escola Única, de que aqueles que cumprem uma trajetória escolar longa são intelectualmente os mais capazes contribui para a valorização dos trabalhadores nãomanuais (classe média) relativamente aos trabalhadores manuais. Tal valorização significa em termos concretos: a) a melhoria da posição econômica relativa da classe média: melhores salários, melhores condições de trabalho, mais vantagens materiais etc.; b) o crescimento do prestígio social da classe média: aproximação, nos terrenos da vida social e da vida cultural, com relação aos círculos da classe dominante. Na prática, essas duas dimensōes da valorização da classe média se interconectam e se realimentam reciprocamente.

É, portanto, o lugar específico que a classe média ocupa na estrutura de classes do capitalismo que a tem levado, no Brasil e noutras sociedades em transição para o 
capitalismo ou já capitalistas, a se colocar na vanguarda da luta pela escola pública e pela universalização da escolarização de base. Enquanto a ação educacional da burocracia estatal dos Estados burgueses emergentes se deveu estritamente à motivação política de promover a integração ideológica do proletariado à ordem social vigente, os sistemas nacionais de educação em processo de implantação tenderam a assumir um caráter dual. Isto é, tais sistemas se inclinaram a ministrar uma educação para os pobres e uma educação para os ricos: o caráter altamente elitista dos Lycées na França e das Public Schools na Inglaterra são evidências que contribuem para atestar essa dualidade. Inversamente, quando a classe média iniciou seu processo de ascensão política em fins do século XIX, emergiu progressivamente uma pressão social a favor da instauração de uma Escola Única; isto é, um aparelho escolar que ministrasse a mesma educação (supostamente, de qualidade) para todas as classes sociais.

É importante insistir no fato de que a classe média assume esse papel mesmo quando muitos dos seus membros preferem inscrever os seus filhos em escolas particulares. Pesquisa recente de João Batista Araújo e Simon Schwartzman (2002) revelou que apenas $20,5 \%$ dos professores da rede municipal do Rio de Janeiro matricularia os seus filhos numa escola pública, o argumento fundamental para descartar essa alternativa sendo a "falta de qualidade" no ensino público, do qual eles próprios fazem parte. ${ }^{6}$ Essa atitude, à primeira vista, parece contraditória. Uma vez analisada à luz do quadro teórico acima apresentado, ela se revela uma expressão adequada da ideologia escolar da classe média.

\section{UMA ANÁLISE HISTÓRICA DOS OBSTÁCULOS POLÍTICOS À CONCRETIZAÇÃO DO DIREITO À EDUCAÇÃO NO BRASIL}

Devemos agora utilizar o quadro sociológico acima esboçado na análise da evolução do direito à educação no Brasil. Digamos desde logo que a análise histórica da formação social brasileira confirma o elemento central desse quadro. As classes sociais fundamentais da sociedade capitalista - a classe capitalista e as classes trabalhadoras manuais - não podem assumir um compromisso aberto e durável com o projeto de universalização da escolarização de base e de concretização do direito universal de entrada no sistema escolar. Justamente por isso, a concretização da primeira dimensão do direito à educação - o direito de entrada no sistema escolar - depende da atuação política de uma terceira classe social: a classe média. Mais especificamente: a concretização do direito à educação, enquanto direito de entrada no sistema escolar, depende de três condições. Primeira condição: a classe média já deve estar formada como classe social autônoma, suficientemente diferenciada da classe dominante. Segunda condição: a classe média já deve ter adquirido um peso numérico e social considerável. Terceira condição: a classe média já deve estar apta a atuar como força política independente, se não durante todo um período histórico, pelo menos em algumas conjunturas cruciais de um mesmo período histórico.

Tentemos demonstrar que, enquanto a classe média brasileira não preencheu as três condições nomeadas acima, o direito à educação não se concretizou. A Constituição 
imperial de 1824 estabeleceu o princípio da "instrução elementar gratuita para todos"; e essa declaração constitucional parece efetivamente revolucionária, sobretudo quando se tem em conta o caráter escravista da sociedade imperial. Contudo, a leitura da íntegra do texto constitucional nos revela que a decretação do princípio da "instrução elementar gratuita para todos" não se fez acompanhar da decretação da obrigatoriedade do ensino elementar, cujas implicações práticas seriam: a) a obrigação dos pais de inscreverem os seus filhos em alguma unidade de ensino elementar; b) a obrigação do aparelho estatal de oferecer ensino elementar gratuito aos necessitados. E, mais que tudo, a Constituição imperial de 1824 não discriminou recursos orçamentários fixos a serem aplicados em instrução elementar. Pode-se portanto deduzir que o compromisso desse texto legal com o direito à educação foi sobretudo um compromisso simbólico, destinado a produzir mais efeitos políticos externos que internos. Ou melhor: a instauração de um embrião de direito à educação - ensino elementar gratuito, porém sem recursos orçamentários próprios, e não obrigatório - fez parte de um conjunto de garantias verbais que as classes dominantes escravistas do Brasil procuraram dar ao grande Estado capitalista emergente: a Inglaterra. Através de múltiplas fórmulas constitucionais, os latifundiários escravistas e os traficantes de escravos brasileiros procuravam convencer os setores dirigentes da monarquia inglesa de que o Estado brasileiro em formação desde 1822 era um Estado liberal, cujo fundamento material só podia ser uma sociedade já plenamente civilizada, à altura das sociedades européias. Na realidade, o Estado imperial brasileiro, não obstante o seu apelo a dispositivos ideológicos burgueses e a fórmulas jurídicas de feitio liberal, delineava-se como um Estado escravista mercantil, que articulava a economia agrária escravista brasileira ao mercado mundial e que funcionava preponderantemente segundo os interesses de latifundiários escravistas e de traficantes de escravos. Nesse tipo de Estado, só poderia reinar a total confusão entre "ordem pública" e "ordem privada": os recursos materiais e organizacionais do Estado eram os próprios recursos pessoais dos funcionários públicos, e estes eram invariavelmente membros das classes dominantes. Durante muito tempo, inexistiram, sob o Estado imperial, uma moeda nacional e mesmo um orçamento público digno desse nome (o que se explica pelo fato de que, tanto do ponto de vista econômico quanto do ponto de vista político, só era viável a tributação do "setor externo" da economia imperial: as exportaçôes e as importaçôes).

Num contexto histórico desse tipo, a declaração constitucional do direito subjetivo individual à educação de base só poderia ser ilusória. As classes dominantes escravistas latifundiários e traficantes de escravos - tinham um interesse quase nulo em propiciar o acesso dos seus trabalhadores à instrução elementar. Por isso mesmo, haviam se implantado, durante o período colonial, dispositivos legais proibindo aos senhores educarem os seus escravos. Quanto à classe média, ela praticamente inexistia no Brasil imperial: o aparelho estatal ainda não tinha se profissionalizado nem gerado conseqüentemente um extenso corpo burocrático, e os escassos profissionais não-manuais ainda não se destacavam, do ponto de vista econômico e social, das classes dominantes, prestando serviços pessoais a uma clientela de alta renda conquistada através de relaçóes familiares e sociais, e não num mercado impessoal. Inexistia, portanto, no Brasil imperial, uma classe social que pudesse lutar pela concretização do dispositivo constitucional que garantia aos homens livres a faculdade individual de exigir instrução elementar gratuita para os seus filhos. 
A Constituição republicana de 1891, que consagrou juridicamente a Revolução política burguesa de 1888 - 1889, surpreendentemente não avançou, com relação à Constituição imperial de 1824, no terreno específico do reconhecimento do direito à educação. $\mathrm{O}$ texto constitucional faz alusão à existência do ensino oficial; porém, ao contrário do que se poderia esperar, não estabelece a obrigatoriedade do ensino elementar. A novidade introduzida por esse texto no terreno educacional é uma decorrência da revogação do estatuto de "religiāo de Estado" gozado no Império pelo catolicismo romano. Ou seja, a Constituição de 1891 decreta a laicidade do ensino oficial, nos termos em que os positivistas encaravam a laicidade: isto é, como proibição do ensino de qualquer religião nas escolas públicas, visto a religião ser o reino da superstição e a própria negação da ciência.

É preciso interpretar em termos históricos esse descompromisso da Constituição republicana de 1891 com o direito à educação. Não é possível atribuí-la, como o fizeram alguns autores, à "distração" ou ao "descuido" dos legisladores republicanos. Em pleno curso de uma Revolução política burguesa - processo social em que os objetivos de classe antagônicos necessariamente se explicitam ao máximo -, as omissões dos legisladores constitucionais sobre questões cruciais da vida social jamais se deveriam a fatores acidentais ou "inorgânicos". Voltemos, portanto, à análise das conexões entre a legislação educacional e as tendências ideológicas duradouras das classes sociais em confronto.

A abolição da escravidão, em 1888, não foi suficiente para transformar os latifundiários numa classe social empenhada em instruir, ainda que minimamente, os seus trabalhadores. Após 1888, os latifundiários continuaram a temer que a instrução servisse como instrumento para a organização de revoltas no campo. Eles podiam propor aos seus trabalhadores, no máximo, a escolinha de fazenda, onde o ensino estaria sob o seu estrito controle. E tendiam, complementarmente, a se opor à consagração legal do direito à educação. Na Conferência Interestadual do Ensino Primário (1926), o ponto de vista retrógrado das classes dominantes rurais brasileiras encontrou perfeita tradução na intervenção de Noé Azevedo, que declarou que "...não vale a pena meter muitas idéias na cabeça do povo"; bem como na de Azevedo Sodré, para quem se deveria deixar tranqüilos "...os iletrados adultos que trabalham, produzem, não fazem revoluções, não perturbam nem anarquizam nosso meio".

Já os industriais eram um grupo social insignificante no momento da Proclamação da República; porém, o avanço da indústria em São Paulo, ao longo das duas primeiras décadas do século XX, foi convertendo a burguesia industrial num grupo social progressivamente mais influente, ainda que politicamente subordinado aos desígnios do capital mercantil exportador (os negociantes de café), absolutamente hegemônico dentro do PRP. Qual terá sido a atitude do empresariado industrial com relação à educação das massas? A maior parte da mão-de-obra urbana estava então alocada no segmento produtivo que ainda vivia num estágio manufatureiro e pré-industrial; ${ }^{8}$ e tinha, portanto, de ostentar um nível de qualificação que a aproximava mais dos artesãos que dos operários da linha de montagem industrial. O empresariado industrial tinha, conseqüentemente, todo o interesse em estabelecer um controle pessoal e direto sobre a sua mão-de-obra e em evitar a rotatividade da força de trabalho, já que a substituição dos trabalhadores qualificados não era fácil. Dentro dessa orientação, os industriais de São Paulo e de outras regiōes passaram, através de lideranças como Jorge Street, a se opor à intervenção 
do Estado em qualquer assunto concernente às classes trabalhadoras, inclusive a educação elementar. E, como estratégia alternativa, a burguesia industrial se lançou na prática do filantropismo e do assistencialismo, cuja verdadeira função era impedir a circulação livre da mão-de-obra qualificada no mercado de trabalho urbano e nada tinha a ver com o reconhecimento de "direitos" dos trabalhadores industriais. A melhor expressão dessa estratégia controladora, a que se procurava conferir a aparência da filantropia, foi a criação, ao lado das indústrias, de vilas operárias, fornecedoras de serviços pessoais (inclusive educação primária) aos trabalhadores e às suas famílias.

A oposição do empresariado industrial da Primeira República à intervenção estatal na educação de massa foi bem sucedida, já que o princípio da educação elementar pública, gratuita e obrigatória não foi consagrado no texto constitucional de 1891 nem nas demais leis desse período (emendas constitucionais ou leis ordinárias). E, de um modo mais geral, os representantes políticos da burguesia industrial no Congresso se empenharam em barrar todo e qualquer projeto de lei que prescrevesse a intervenção estatal nas relações entre capital e trabalho: projetos de limitação do trabalho infantil, projetos para a melhoria das condições de vida e de trabalho dos trabalhadores assalariados etc.

Do ponto de vista da sociologia histórica, questão intrigante é aquela concernente à postura educacional da classe média durante pelo menos as três primeiras décadas da Primeira República: por que essa classe social, que desempenhou um papel revolucionário na formação do Estado burguês entre 1888 e 1891, não desempenhou um papel equivalente na luta pela afirmação do direito universal à educação e pela implantação da educação de massa no Brasil? Mais precisamente: por que a classe média não propôs, no processo constituinte de 1889-1891, o reconhecimento do princípio da educação elementar pública, gratuita e obrigatória?

A explicação sociológica e histórica mais plausível para essa omissão da classe média republicana quanto à implantação de um sistema de educação pública parece ser a que se segue: a defesa do ensino laico, em oposição aos desígnios de uma Igreja Católica ainda fortemente vinculada às classes dominantes, deve ter canalizado todo ímpeto pequenoburguês de destruição da sociedade aristocrática, da ordem social fundada no privilégio (e não, no mérito pessoal) e do Estado de bases estamentais. Para a classe média daquele momento histórico, a tarefa política fundamental consistia em libertar a sociedade da opressão aristocrática exercida com a mediação do Estado. Era, portanto, pouco provável que esse grupo social passasse imediatamente a crer na capacidade do Estado - mesmo que transformado pela revolução republicana - de implementar medidas positivas nos diferentes terrenos da vida social. Dado o perigo de uma ingerência despótica na vida social, melhor seria assegurar a retração do Estado e lutar para que a sociedade, por si mesma, reconhecesse o princípio do mérito pessoal e bloqueasse a vigência do privilégio. Tendo derrubado o Estado "aristocrático" do Império, a classe média revolucionária, sem dúvida influenciada pelas teses educacionais do positivismo comtiano, ${ }^{9}$ inclinava-se, naquela fase inicial de transição para uma sociedade burguesa, para a defesa de um Estado "neutro", mais que para a apologia de um Estado orientado para a "intervenção" a favor do mérito pessoal.

A Revolução de 1930 promoverá um salto qualitativo no terreno da declaração constitucional do direito à educaçãa. A Constituição de 1934 - coroamento legal do processo 
revolucionário - estabelece, pela primeira vez na história constitucional do Brasil, o direito universal de entrada no sistema escolar. $\mathrm{O}$ texto constitucional não se limita a declarar obrigatório e gratuito o ensino elementar; ele também afirma o papel central da escola pública dentro do sistema educacional e atribui recursos orçamentários fixos à educação. Tal mudança constitucional se explica, de um modo geral, pelo novo contexto histórico. A crise econômica mundial de 1929 dificultou momentaneamente o intercâmbio entre países desenvolvidos e países atrasados; e tornou necessária a aceleração da industrialização nos países atrasados já alçados a um patamar industrial mínimo. Conseqüentemente, intensificou-se a necessidade de qualificação mínima da mão-de-obra urbana e de fornecimento de instrução elementar às massas urbanas.

Do ponto de vista da sociologia histórica, é, entretanto, fascinante que não tenha sido a classe capitalista, e sim a classe média, o agente social capaz de traduzir em sua ação política as exigências objetivas do processo de industrialização. No processo constituinte de 1933-1934, enquanto as classes dominantes se aglutinaram em torno da liderança educacional exercida pela Igreja Católica, os segmentos civil, burocrático e militar da classe média (representados pelas lideranças tenentistas, nacionalistas e escolanovistas), buscaram implantar as bases constitucionais mínimas para a concretização do direito universal de entrada no sistema escolar.

É curioso notar que, nos dois momentos históricos da vida republicana brasileira em que o regime democrático foi substituído por um regime ditatorial, a classe média declinou como força política independente, tornando-se uma base de apoio passiva do novo regime. Ora, o declínio político da classe média teve conseqüências no terreno da legislação constitucional sobre a educação. A Carta Constitucional de 1937, implantada pelo Estado Novo, e a Carta Constitucional de 1967, imposta pelo Regime Militar, suprimiram, ambas, um dispositivo essencial para a concretização do direito universal de entrada no sistema escolar: a atribuição de recursos orçamentários fixos à educação.

Nos anos 80 , a ascensão do movimento democrático, no qual o conjunto da classe média e o movimento docente ${ }^{10}$ tinham um papel decisivo, levou a novos avanços no terreno da declaração constitucional do direito à educação. No processo constituinte de 1986-1988, foram frustrados os desígnios dos lobbistas do ensino privado, sempre interessados em diminuir, em proveito próprio, a presença do Estado na área educacional; bem como os anseios da classe capitalista em geral, sempre interessada em reduzir a zero os recursos orçamentários para a educação e em canalizar os recursos financeiros do Estado para outras rubricas mais produtivas para o capital, como as obras de infraestrutura e o apoio financeiro à produção. A Constituição de 1988 enriqueceu a enunciação das condições legais de concretização do direito universal de entrada no sistema escolar. O texto constitucional não só reafirmou o princípio do ensino fundamental obrigatório e gratuito, como também reintroduziu a atribuição - suprimida na Carta Constitucional de 1967 - de recursos orçamentários fixos para a educação. Além disso, criou salvaguardas institucionais, gerais ou específicas, à disposição dos pais em caso de descumprimento do chamado "direito à educação": o princípio da responsabilização jurídica da autoridade não-cumpridora de suas obrigações no plano educacional; o mandado de injunção; o habeas data; e um novo Ministério Público, razoavelmente independente diante do Poder Executivo. 
Sobre essa base legal, os governos social-democratas da década de 1990, traduzindo anseios ideológicos da classe média, buscaram promover a ampliação da oferta de ensino fundamental, apoiados nas propostas internacionais de priorização do ensino fundamental, nos países periféricos, em detrimento do ensino universitário.

\section{UMA CARACTERIZAÇÃO DOS OBSTÁCULOS POLÍTICOS À CONCRETIZAÇÃO DO DIREITO DE SAÍDA DO SISTEMA ESCOLAR}

Pode-se hoje, com uma certa dose de tolerância, reconhecer que o direito universal de entrada no sistema escolar está tendencialmente concretizado no Brasil. Inversamente, o maior déficit em matéria de direito à educação consiste na falta de garantias concretas quanto à saída do sistema escolar. Fenômenos como o fracasso escolar, o retardo escolar, a evasão escolar e o iletrismo inviabilizam, para grande parte dos alunos, uma saída normal do sistema escolar. A maioria da clientela escolar não cumpre uma trajetória escolar longa; ela realiza apenas uma trajetória escolar curta, quando não é prematuramente expulsa do sistema escolar. Isso significa que há obstáculos de monta à concretização do direito universal de saída do sistema escolar.

A análise sociológica de tais obstáculos tem necessariamente de começar pela má distribuição de renda no Brasil. O baixo nível dos rendimentos do trabalho manual torna permanentemente altos, para a massa trabalhadora, os custos indiretos da escolarização, forçando os alunos de origem popular a abandonar a escola e a se integrar ao mercado de trabalho ou a buscar um trabalho informal. Caso a participação relativa dos trabalhadores manuais na renda nacional fosse radicalmente incrementada, os pais trabalhadores teriam mais meios materiais para reter os seus filhos na escola por mais tempo, independentemente de o padrão de ensino corresponder, ou não, às possibilidades ou expectativas dessas crianças. Ora, uma redistribuição radical da renda nacional se choca com os objetivos e as concepções da classe capitalista nacional, para a qual a grande vantagem relativa de economias periféricas como o Brasil é o baixo nível dos salários diretos e indiretos, capaz em princípio de atrair investidores estrangeiros e de viabilizar associações de capitais.

Como esses objetivos e concepções têm influenciado todos os governos brasileiros, inclusive o atual, torna-se difícil imaginar a superação do padrão altamente concentrado de distribuição da renda sem que se supere previamente o próprio modelo vigente de sociedade (vale dizer: o capitalismo). Isso significa que a alta concentração da renda é um obstáculo político duradouro à concretização do direito de saída do sistema escolar.

Se a superação desse obstáculo parece ser difícil dentro dos limites do capitalismo, igualmente difícil se mostra a superação de um segundo obstáculo, que poderíamos classificar mais exatamente como um obstáculo ideológico: a convergência entre o padrão do ensino ministrado na escola pública e o universo cultural/ideológico da classe média. Do alto burocrata de ministério ou de secretaria ao professor, passando pelo diretor, coordenador e supervisor, os agentes do sistema escolar pertencem objetivamente à classe média, estão impregnados da ideologia de classe média e projetam, conseqüentemente, 
para a escola pública um ensino direcionado para o aluno de classe média, implicitamente definido como "aluno normal". A predominância ideológica da classe média no espaço escolar público é o fator em última instância determinante de três características centrais do ensino público: a) ele tende a ser excessivamente teórico; b) ele tende a se basear predominantemente na linguagem escrita; c) ele se acha altamente influenciado por concepções elitistas acerca do homem, da história, da vida social e do conhecimento.

Um ensino ministrado dentro desse padrão tende a negligenciar a vinculação entre produção/transmissão do conhecimento e prática social, a importância da linguagem oral e a contribuição essencial - ainda que prestada de modo indireto - das massas ao avanço da produção, da técnica, da ciência e da organização social. O ensino público desconsidera, portanto, terrenos do conhecimento onde as crianças de origem popular revelam a sua força e se mostram freqüentemente em vantagem com relação às crianças de classe média. E o resultado prático de taxas elevadas de fracasso, retardo e evasão escolares no subgrupo dos alunos da predominância dessa orientação no sistema escolar público só pode ser a ocorrência crescente de mais pobres.

A análise das conseqüências práticas da convergência entre padrão de ensino e ideologia de classe média nos permite vislumbrar a dialética tortuosa e perversa em operação no longo e difícil processo de concretização do direito à educação em qualquer país capitalista. Por um lado, as aspirações sociais da classe média exercem uma influência positiva no terreno educacional, fazendo com que essa classe social lute pela instauração da escola única e do ensino público, gratuito e obrigatório; ou seja, pela concretização do direito universal de entrada no sistema escolar. Por outro lado, essas mesmas aspiraçôes sociais exercem simultaneamente uma influência negativa no terreno educacional, na medida em que solicitam o favorecimento - inconsciente, semi-consciente ou até mesmo consciente - do aluno de classe média dentro do sistema escolar. Esse favorecimento só pode resultar, em termos práticos, no bloqueio às possibilidades de o aluno de origem popular cumprir uma trajetória escolar longa. Ora, tal bloqueio equivale ao bloqueio à concretização do direito universal de saída do sistema escolar.

Procuramos acima sugerir que o aspecto mais dramático desse quadro é o fato de que a atuação positiva da classe média a favor do direito de entrada no sistema escolar e a atuação negativa da classe média contra o direito de saída do sistema escolar estão organicamente ligadas e são expressōes diferenciadas, porém complementares, de uma mesma disposição ideológica. Tal disposição consiste na inclinação a simular uma competição de saber dentro do espaço escolar público; competição essa que só pode ter como resultado formal e oficial a vitória dos alunos de classe média no terreno do mérito escolar. E esse tipo de vitória de classe, ocorrendo dentro de um dos poucos espaços formalmente democráticos da sociedade capitalista, jogará um importante papel na valorização econômica e social dos trabalhadores não-manuais relativamente aos trabalhadores manuais.

Procuramos, através da análise sociológica, indicar que é particularmente difícil promover, dentro dos limites da sociedade capitalista, a superação dos dois grandes 
obstáculos à concretização do direito universal de saída do sistema escolar, que se confunde com o direito efetivo ao cumprimento de uma trajetória escolar longa: a) o padrão altamente concentrado de distribuição da renda; b) a convergência entre o padrão do ensino público e o universo cultural/ideológico da classe média. Essa dificuldade, porém, não exime os educadores de orientação crítica e progressista de proporem uma radical redistribuição de renda no plano nacional e uma revolução cultural dentro da escola pública. Na verdade, só a formulação explícita e aberta dessas propostas abrirá o caminho para a exibição da incapacidade orgânica do modelo capitalista de sociedade de concretizar o direito à educação em todas a suas dimensões. Tais propostas só podem, portanto, assumir a feição política de reivindicaçôes - limite, das quais se sabe desde logo que não terão como ser atendidas a não ser que se promova a superação do modelo capitalista de sociedade. Apresentando-se formalmente como reivindicações, propostas orientadas pela aspiração à mudança social global tendem a produzir um efeito político pedagógico, chamando a atenção da maioria social para os limites estruturais do capitalismo no terreno da educação.

\section{Notas}

1. O tema da escolarização desigual foi lançado por Luiz Antonio Cunha em sua obra já clássica, Educação e desenvolvimento social no Brasil, 3. ed. Rio de Janeiro: F. Alves, 1978. Ver especialmente o capítulo 3, "A escolarização desigual".

2. A ideologia escolar prática é aquela ligada organicamente aos interesses materiais dos agentes coletivos; é ela que orienta efetivamente as açōes práticas desses agentes. No entanto, ela é correntemente ocultada, tanto do próprio agente quanto dos demais agentes, por uma ideologia escolar teórica, que se corporifica num discurso essencialmente endereçado à "opinião pública".

3. Sobre esse ponto, ver Vitor Henrique Paro, Administração escolar / introdução crítica, 11. ed. São Paulo: Cortez, 2002, especialmente o capítulo III, "Transformação social e educação escolar".

4. Sobre uma das experiências mais bem sucedidas de vila operária, consultar Palmira Petratti Teixeira, A fábrica do sonho / trajetória do industrial Jorge Street, Rio de Janeiro: Paz e Terra, 1990, especialmente o capítulo 3, "Jorge Street e a sistematização do controle da mão-deobra: Vila Operária Maria Zélia”.

5. Foi Pierre Bourdieu o sociólogo que formulou um amplo quadro das posturas assumidas pelas diferentes classes sociais com relação à formulação de estratégias educacionais, caracterizando de modo sofisticado a diferença entre as atitudes educacionais do empresariado, da classe média e dos trabalhadores manuais. A esse respeito, ver, por exemplo, o ensaio "Futuro de classe e causalidade do provável”, constante de Pierre Bourdieu, Escritos de educação, 3. ed. Petrópolis: Vozes, 1998.

6. Esses dados constam de matéria publicada na Folha de São Paulo de 30 de março de 2002, p. C3, sob o título: "Professor prefere filho na rede privada".

7. Essas formulações são reproduzidas por Jorge Nagle em Educação e sociedade na Primeira República, São Paulo: EPU/Edusp, 1974, p. 332, nota n. 19. 
8. Sobre esse ponto, consultar Paulo Singer, A formação da classe operária, 4. ed. São Paulo: Atual, 1992, especialmente o capítulo 2, "A formação da classe operária no Brasil".

9. O positivismo comtiano se inclinou a defender a liberdade de ensino, como forma de combater a divulgação oficial da superstição e da metafísica.

10. Do ponto de vista ideológico, o movimento docente tende a atuar como uma vanguarda da classe média, pois a natureza do trabalho docente predispóe os professores para o papel de difusores da ideologia pequeno-burguesa do mérito pessoal.

\section{Referências}

BOURDIEU, Pierre. Escritos de educação. 3. ed. Petrópolis: Vozes, 1998.

CUNHA, Luiz Antonio. Educação e desenvolvimento social no Brasil. 3. ed. Rio de Janeiro: Francisco Alves, 1978.

NAGLE, Jorge. Educação e sociedade na Primeira República. São Paulo: EPU/Edusp, 1974.

PARO, Vitor Henrique. Administração escolar /introdução crítica. 11. ed. São Paulo: Cortez, 2002. SINGER, Paulo. A formação da classe operária. 4. ed. São Paulo: Atual, 1992.

TEIXEIRA, Palmira Petratti. A fábrica do sonho / trajetória do industrial Jorge Street. Rio de Janeiro: Paz e Terra, 1990. 


\section{Political obstacles that restrain the right to education in Brazil}

\section{Abstract}

The aim of this article is to investigate the historical reasons for the gap between two dimensions of the compliance to the right to education in Brazil: the effectuation of the universal right to enter the schooling system and the accomplishment of the right to leave that system. The conclusion of this study is that the middle class is the main agent of the establishment and the evolution of the right to education in Brazil. As the aspirations of this social class are socially limited, the possibilities of full compliance of the universal right to education in Brazilian society are consequently reduced, as long as it is in conformity to the capitalist model of social and economic organization.

Keywords: Education. Right. Trajectory. Strategy. Middle class. School failure.

\section{Les obstacles politiques à la concretisation du droit à l'éducation au Brésil}

\section{Résumé}

L'objectif de ce texte est d'investiguer les raisons historiques du déphasage entre deux dimensions du processus de concrétisation du droit à l'éducation au Brésil : l'effectivation du droit à entrer dans le système scolaire et la réalisation intégrale du droit de quitter ce même système scolaire. La conclusion de cette étude est que la classe moyenne est le principal agent de l'instauration et du développement du droit à l'éducation au Brésil. Comme les aspirations de cette classe sociale sont socialement limitées, le seront aussi les possibilités de réalisation pleine au droit universel à l'éducation dans la société brésilienne et cela aussi longtemps quelle se conforme au modèle capitaliste socio-économique.

Mots clefs : Éducation. Droit. Trajectoire. Statégie. Classe moyenne. L'échec scolaire.

\section{Obstáculos políticos a la concretización del derecho a la educación en Brasil Resumen}

El objetivo del texto es investigar las razones históricas entre dos dimensiones del proceso de concretización del derecho a la educación en Brasil: la efectivación del derecho universal de entrada en el sistema escolar y la realización integral del derecho de salida de este sistema. La conclusión de este estudio es que la clase media es el principal agente de la instauración e del desarrollo del derecho a la educación en Brasil; y como las aspiraciones de esa clase socialmente limitadas, en consecuencia son reducidas las posibilidades de realización integral del derecho universal a la educación en la sociedad brasileña mientras esta esté conformada al modelo socioeconómico capitalista.

Palabras-clave: educación. Derecho. Trayectoria. Estrategia. Clase media. Fracaso escolar.

Recebido: 06.02 .2006

Aceito: 16.03.2006 
